\title{
NULLITY AND INEFFECTIVENESS OF CONTRACTS AS A CONSEQUENCE OF VIOLATION OF EU COMPETITION AND PUBLIC PROCUREMENT RULES ${ }^{*}$
}

\begin{abstract}
The presented paper will focus on the extent of requirements of EU law for nullity or ineffectiveness of contracts in specific areas linked to functioning internal market: competition law, including agreements restricting competition, abuse of dominant position, merger control and state aid, and rules of public procurement. The scope of EU-law-based nullity is quite limited and only Art. 101(2) TFEU provides expressed nullity of agreements restricting competition. In the case of abuse of dominance, nullity of contract constituting abuse of dominant position can be drawn from the principle of effectiveness of EU law. Validity or nullity of contracts violating suspension clause in merger control regime are assessed in two periods - before decision on merger and after decision of the Commission. State aid regime cannot rely on EU-law-based nullity of contracts that violate EU state aid rules. Finally, public procurement rules appear the most complex in this context since they operate with the "right" of the contracting authority to terminate contract and power of revision authority to declare "ineffectiveness" of illegally awarded contract, and therefore revision of directives is suggested.

Keywords: EU Law, competition law, public procurement, nullity, ineffectiveness.
\end{abstract}

\section{Introduction}

Establishing internal market of the European Union (EU) relies on plenty rules embedded in primary law as well as secondary law. Moreover, rules aimed at establishing the EU's internal market are split to exclusive competence of the EU under Art. 3 of the Treaty on the Functioning of the European Union (TFEU) and shared competence under Art. 4 TFEU. While, in particular, "competition rules necessary for the functioning of the internal market" is exclusive competence of the EU [Art. 3(1)(b) TFEU], the majority of rules of internal market fall into shared competence of the EU and the Member States [Art.

\footnotetext{
*Associate Professor at the Faculty of Law of Comenius University in Bratislava, Slovakia, e-mail: ondrej.blazo@flaw.uniba.sk, ORCID: 0000-0001-9721-8724, Web of Science ResearcherID: E-3924-2013.

${ }^{* *}$ The paper was prepared within project APVV-17-0641 "Improvement of effectiveness of legal regulation of public procurement and its application within EU law context”.
} 
4(1)(a) TFEU]. Distinguishing between exclusive competence and shared competence is crucial for application of the principle of subsidiarity, while the principle of proportionality is applicable equally. Law-making of the EU shall also respect "national identity" of the Member States [Art. 3(2) of the Treaty on European Union (hereinafter "TEU”)]. This principle does not, however, undermine the principle of the primacy of EU law itself and constitutes limited exemption from general primacy of EU law restricted merely to the cases when European acts which do not respect fundamental values of the Member States (Besselink, 2010, pp. 47-48). Hence, the Member States cannot refer to national identity as an excuse from Art. 4(3) TEU, i.e. principles of sincere cooperation and loyalty, and together with the principles of proportionality and subsidiarity, limit the scope and extent of actions of the EU. There is long-time respected principle of procedural autonomy of the Member States in achieving aims of the EU that is gradually shaped by (1) general requirements of the principles of effectiveness of EU law and equivalence of application of EU law (e.g. Delicostopoulos, 2003; Zingales, 2010) as well as by (2) harmonization directives dealing with particular question of administrative law, civil and criminal procedure. There is no general competence of the EU to harmonize private law (Schmid, 2002), nonetheless EU law significantly encroaches on several areas of substantive private law of the Member States, in particular company law (e.g. Mock, 2002 and literature cited therein) and consumer law (Weatherill, 2012).

From the times of Roman law, nullity (including nullity of contracts) has been deemed as an extreme measure and consequence of errors linked to legal act (Scalise, 2014). Therefore, serious interests of public policy must be established in order to nullify or cause ineffectiveness of the private arrangements relying on contractual freedom. Generally, in the EU, validity, nullity and effectiveness of private arrangements and contract is a domain of private law regimes of the Member States. Hence there is no general competence of the EU to harmonize private law, requiring certain rules regarding nullity or ineffectiveness of private contracts must be stipulated directly or indirectly in EU law in irregular occurrences due to principles of proportionality and subsidiarity.

The presented paper will focus on the extent of requirements of EU law for nullity or ineffectiveness of contracts in specific areas linked to functioning internal market: competition law, including agreements restricting competition, abuse of dominant position, merger control and state aid, and rules of public procurement. This sphere of rules of internal market was selected because these rules do not deal with particular contracts between individuals protecting specific individual (e.g. consumer protection) but they protect functioning of the system of EU internal market as a whole.

\section{Agreements restricting competition}

Regarding nullity of contracts, Art. 101(2) TFEU is the most straightforward provision of EU law invalidating private contracts contrary to EU law directly via the primary law: "Any agreements or decisions prohibited pursuant to this Article shall be automatically void". Hence nullity itself is directly laid down by primary law and does not 
require any further national regulations, there is still a margin for assessment of the scope of the prohibition (i.e. to what extent are arrangements between undertakings void) and time framework of the prohibition.

Well-established case law of the Court of Justice of the European Union (hereinafter $\mathrm{CJEU}$ ) noted that it is necessary to distinguish between contract between undertakings under national private law and prohibited agreement. In Société Technique Minière (L.T.M.) $v$ Maschinenbau Ulm GmbH (M.B.U.) (1966) the CJEU explained that "This provision, which is intended to ensure compliance with the Treaty, can only be interpreted with reference to its purpose in community law, and it must be limited to this context. The automatic nullity in question only applies to those parts of the agreement affected by the prohibition, or to the agreement as a whole if it appears that those parts are not severable from the agreement itself. Consequently any other contractual provisions which are not affected by the prohibition, and which therefore do not involve the application of the treaty, fall outside community law." Therefore it is necessary to identify only those parts of the agreement that are contrary to Art. 101(1) TFEU, since provision in Art. 101(2) TFEU that agreements prohibited pursuant 101(1) TFEU "shall be automatically void applies only to those parts of the agreement which are subject to the prohibition, or to the agreement as a whole if those parts do not appear to be severable from the agreement itself" (Consten/ Grundig, 1966). This approach of the court is, in fact, demonstration of a limited competence of the EU and the principle of conferral. The CJEU requires interference into private law of the Member States to be as minimal as possible and nullity of the contract as a whole is considered extreme and ultimate consequence that can be applied only if effect of Art. 101(2) TFEU cannot be achieved otherwise, e.g. confirmed in CEPSA (2008, par. 80): "[...] automatic nullity provided for in Article 81(2) EC affects a contract in its entirety only if the clauses which are incompatible with Article 81(1) EC are not severable from the contract itself. Otherwise, the consequences of the nullity, in respect of all the other parts of the contract, are not a matter for Community law".

Such a limited scope of nullity stemming from EU law can have serious consequences regarding arrangement of relations between undertakings that are parties to the agreement caught by Art. 101(1) TFEU. In particular, vertical agreements establish transactions regarding goods, services, payments, etc. and restrictive provisions form merely a part of such agreements. The CJEU confirmed e.g. in Société de vente de ciments v Kerpen \& Kerpen (1983) that there is no consequence of nullity for other parts of the agreement that are not contrary to Art. 101(1) TFEU as well as "any orders and deliveries made on the basis of the agreement, and the resulting financial obligations are not a matter for community law. Such consequences are to be determined by the national court according to its own law. "Similarly, it is within the ambit of national regulation to provide guidance to the parties to an agreement regarding duty to adjust the agreement in order not to be contrary to Art. 101(1) TFEU, e.g. explained by the CJEU in VAG France (1986, par. 15): "It is on the basis of national law that it is necessary in particular to determine whether such incompatibility may have the effect of obliging the contracting parties to amend the content of their agreement in order to prevent it from being void." 
Art. 101(2) TFEU stresses "automatic" nullity of agreements and decisions violating Art. 101(1) TFEU. The direct effect of Art. 101 TFEU is also underlined by Art. 1(1) EU Regulation 2003: "Agreements, decisions and concerted practices caught by Article 81(1) of the Treaty which do not satisfy the conditions of Article 81(3) of the Treaty shall be prohibited, no prior decision to that effect being required." Hence agreement and decision violating Art. 101(1) TFEU is void on a basis of EU law notwithstanding private-law rules regarding nullity of contracts of particular state. Moreover, in the case of demonstrated infringement of Art. 101(1) TFEU, courts of the Member States cannot assess whether the agreement or decision is null under national law and it is merely empowered to declare or confirm its ex lege nullity. Another consequence of the "automatic" nullity of agreement is its erga omnes character, as it was described in Béguelin (1971, par. 29): "Since the nullity referred to in article 85(2) is absolute, an agreement which is null and void by virtue of this provision has no effect as between the contracting parties and cannot be set up against third parties."

Under the judgment in Haecht II, the time framework of the nullity of agreement or decision appears to be simple: "(26) Such nullity is therefore capable of having a bearing on all the effects, either past or future, of the agreement or decision. (27) Consequently, the nullity provided for in article 85(2) is of retroactive effect" (Haecht II, 1973, par. 26 and 27). This simple point of view is applicable in the case of cartels and other hard-core restrictions. Prohibition of agreements that do not have as their object to restrict competition depends on real effects of an agreement and also on market situation. Due to dynamics of market conditions the agreement can be caught by prohibition of Art. 101(1) TFEU and later fall from the prohibition as well as fulfil conditions under 101(3) TFEU and lose benefits of that legal exemption during the "life" of the agreement. Application of Art. 3 of the EU Regulation 2010 is an apparent example for such consideration, since the application of the block exception for vertical restriction depends on the threshold of $30 \%$ market share. Indeed, if the agreement restricting does not fulfil criteria under the EU Regulation 2010 is not automatically prohibited and still benefit from Art. 101(3) TFEU, the market share can dynamically influence assessment effect of the agreement on competition and trade on internal market. Therefore, it is much more appropriate not to consider an agreement null and void $a b$ initio, i.e. from the moment when it was concluded, but null back from the moment when it violates Art. 101(1) TFEU or falls from the exemption laid down by Art. 101(3) TFEU. Similarly, Art. 101(2) TFEU cannot stipulate nullity of an agreement for the periods in the future when it does not infringe Art. 101(1) TFEU, either by nonexistence of restrictive effects or by benefitting from the exemption under Art. 101(3) TFEU. Moreover, this point of view brings different understanding of nullity under Art. 101(2) TFEU, i.e. an autonomous EU-law nullity independent from nullity of the contracts under national private law. Indeed, national private law can stipulate nullity of contracts violating law, however it is within the ambit of national regulation to decide whether it is possible to "renew" effect of previously null agreement when it ceases to infringe law or not. Notwithstanding nullity of the agreement under substantive national private law, the courts of the Member States cannot provide grant protection and effects to the agreements null pursuant to Art. 101(2) TFEU. 


\section{Abuse of dominant position}

Comparing to agreements restricting competition, there is no corresponding provision in regulation covering prohibition of abuse of dominant position enshrined in primary law in Art. 102 TFEU. While in Art. 101 TFEU the contractual element in the case of agreements restricting competition is always present, in unilateral practices covered 102 TFEU, conclusion of contract and performance thereof it is not always present, e.g. abuse of dominant position can be constituted by refusal to conclude an agreement. Due to absence of explicit EU law regulation, the CJEU was more cautious in asserting nullity of contract constituting abuse of dominant position and in BRT/SABAM (1974, par. 14) it left to the national judge to decide on validity of contracts: "If abusive practices are exposed, it is also for the court to decide whether and to what extent they affect the interests of authors or third parties concerned, with a view to deciding the consequences with regard to the validity and effect of the contracts in dispute or certain of their provisions." The necessity of nullity or at least ineffectiveness of contractual arrangements constituting abuse of dominant position under Art. 102 was more apparent in Ahmed Saeed Flugreisen (1989, par. 45): "[...] the competent national administrative or judicial authorities must draw the inferences from the applicability of the prohibition and, where appropriate, rule that the agreement in question is void on the basis, in the absence of relevant Community rules, of their national legislation." Hence the wording in Ahmed Saeed Flugreisen is an expression of the instruction for loyal fulfilment of duties of the Member State required by EU law enshrined in Art. 4(3) TEU, i.e. to "take any appropriate measure, general or particular, to ensure fulfilment of the obligations arising out of the Treaties or resulting from the acts of the institutions of the Union." Summing up, even in the case of absence of an explicit obligation included in Art. 102 TFEU and notwithstanding national rules of private law on nullity of contracts, EU law requires the Member States not to provide legal protection and effect to contracts that constitute abuse of dominant position. Therefore, from the point of view of EU law, legal ineffectiveness can be more appropriate in connection with Art. 102 TFEU, however, in fact, the effects are equivalent to those of nullity of contract.

Because of absence of detailed and comprehensive case law regarding "nullity" under Art. 102 TFEU, commentators suggest employing rules established regarding 101(2) TFEU (e.g. O’Donoghue \& Padilla, 2020, p. 1208 and literature cited therein), in particular, absolute character, (in)separability of clauses, limited scope of effects of EU law on contracts, nullity ex tunc. Equally to agreements restricting competition, the concept of absolute effects of prohibition of abuse of dominant position relies on automatic effect of the prohibition that is enforceable under Art. 1(3) EU Regulation 2003 without prior declaratory decision on infringement itself: "The abuse of a dominant position referred to in Article 82 of the Treaty shall be prohibited, no prior decision to that effect being required". 


\section{Concentrations}

Comparing to agreements restricting competition and abuse of dominant position, mergers are not subject to prohibition but subject to control by competition authorities. The EU adopted ex ante mandatory regime of merger control (for types of merger regimes see, e.g. OECD, 2019) coupling notification duty and suspension clause [Art. 7(1) EU Regulation 2004]. Apparently, prior to decision of the European Commission on merger, there is no reason for doubt regarding validity of contractual arrangements that constitute merger itself existence of valid private contract (or other private-law act) is essential for the existence of merger.

However, validity of all transactions contravening suspension rules shall be dependent on decision on the merger itself [Art. 7(4) EU Regulation 2004]. Violation of suspension, i.e. implementation of transaction constituting merger prior its approval, is not connected with automatic nullity and transactions constituting or implementing concentration are null only if the concentration is declared incompatible with the internal market. The situation is much more complex when the concentration is approved only together with conditions. The broad wording of Art. 7(4) EU Regulation 2004 enables to invalidate not only transactions in the case of prohibition of concentration but also transactions contrary to conditions of approval of the concentration. On the other hand, transactions are valid even if they violate suspension clause if they do not contravene final decision on the concentration (Éditions Odile Jacob v Commission, 2012, par. 38-40).

Hence, validity and enforceability of transaction can be split into two phases. The first phase covers transactions prior to clearance of the concentration by the European Commission. Except cases exempted by Art. 7(2) and Art. 7(3) EU Regulation 2004, every activity of parties of the concentration aimed to implement concentration contravenes suspension duty under Art. 7(1) EU Regulation 2004. These "gun jumping" activities of undertakings are subject to sanctions under Art. 14(2)(b) EU Regulation 2004 (fines not exceeding $10 \%$ of undertakings' turnover). However, there is not explicit provision of EU law dealing with nullity or validity of transactions contravening suspension duty prior the decision of the Commission. Rationale of application approach similar to effect of abuse of dominant position is apparent and approach similar to that stipulated in Ahmed Saeed Flugreisen shall be employed. Even in the absence of EU rules or national rules, the courts of the Member States cannot provide legal protection to such transactions. Therefore, in terms of explicit rules, even EU remains mute regarding private-law effects of "gun jumping", there is implied requirement of legal ineffectiveness of these transactions. Agreements violating suspension duty are rather "suspended" than "null" because after final clearance of the concentration they are deemed valid under Art. 7(4) EU Regulation, even though they were illegal in the moment of its occurrence. Nonetheless, such agreements can be also caught by prohibition of Art. 101 TFEU and to follow this antitrust regime, certainly, including "ancillary restraints" principles (Cf. Nazzini, 2006).

The situation is completely different in the second phase, i.e. after decision on the concentration. If the concentration is declared incompatible with internal market, all 
"gun-jumping" transactions follow the legal fate of the concentration, hence they are not valid $a b$ initio. This nullity of transaction stems directly from EU law independently from national legal orders.

The scope of application of Art. 7(1) EU Regulation 2004 was defined by the CJEU in Ernst \& Young (2018, par. 49) case and the suspension clause does not catch"[...] transactions, despite having been carried out in the context of a concentration, are not necessary to achieve a change of control of an undertaking concerned by that concentration" even though these transactions "may be ancillary or preparatory to the concentration [...]". Hence only transaction related to concentration that "[...] present a direct functional link with its implementation[...]" and their implementation is therefore "likely to undermine the efficiency of the control of concentrations" is caught by Art. 7(1) EU Regulation 2004 with effects to Art. 7(4) thereof (a contrario, Ernst \& Young, 2018, par. 49).

\section{State aid}

The aim of the prohibition of aid granted by states (for more details regarding definitions and concepts of state aid see e.g. Cortese, 2020; Kubera, 2020; Pärn-Lee, 2020) is clearly stipulated in provision of Art. 107(1) TFEU: avoid any act of public authority that "distorts or threatens to distort competition [...], in so far as it affects trade between Member States." Although it employs similar notions and concepts to those used in competition rules for undertakings (Art. 101 and 102 TFEU) (e.g. distortion of competition), the concept is completely different from philosophical and economic point of view and Art. 107 TFEU is linked back to Art. 28 et seq. TFEU and Art. 110 TFEU, i.e. rules barring the Member States to segment internal market by their actions, particularly of protectionist or discriminatory nature. Therefore, compared to Art. 101 and 102 TFEU as well as merger control, it is hard to identify direct effect of Art. 107(1) TFEU itself. EU Regulation 2015 that introduces procedural rules regarding state aid is oriented mainly to prevent granting aid contrary to EU law and in the case granting unlawful aid to recover it. There is no explicit provision of nullity of contracts by which the aid was awarded. Moreover, the public body is not obliged (in fact it is not allowed) to recover unlawful state aid if it is contrary to general principles of EU law [Art. 16(1) EU Regulation 2015], particularly when legitimate expectations on legality of aid were created (for details regarding test of legitimate expectations see Pinto, 2016; Ritzenhoff, 2014, p. 733).

Contrary to substantive provision regarding state aid based on Art. 107 TFEU, provision of Art. 108 (3) in fine TFEU has direct effect and may be invoked for private enforcement: "The Member State concerned shall not put its proposed measures into effect until this procedure has resulted in a final decision." The CJEU confirmed powers of the courts of the Member State to enforce Art. 108(3) TFEU not only in cases of recovery decision of the European Commission, but also in "stand alone" cases: "The last sentence of Article 88(3) EC is based on the preservative purpose of ensuring that an incompatible aid will never be implemented. That purpose is achieved first, provisionally, by means of the prohibition which it lays down, and, later, definitively, by means of the Commission's 
final decision, which, if negative, precludes for the future the implementation of the notified aid plan. The intention of the prohibition thus effected is therefore that compatible aid may alone be implemented. In order to achieve that purpose, the implementation of planned aid is to be deferred until the doubt as to its compatibility is resolved by the Commission's final decision." (CELF I, 2008, par. 9). Although Member States are addressees of Art. 108(3) TFEU, providers of aid can directly face claims arising from violation of said provision. On the other hand, application of Art. 108(3) TFEU by national courts is limited by procedural rules of respective Member States (Goyder \& Dons, 2017; Gyárfaš, 2017; Honoré \& Jensen, 2017; Jouve, 2017; Köhler, 2017; Martin-Ehlers, 2017; Ordóñez-Solís, 2017; Pastor-Merchante, 2016; Stehlík, 2018). Request from the EU law to impose nullity on contract or provision on nullity of such contracts was not even identified by the European Commission since it identified following private law remedies: (a) preventing the payment of unlawful aid; (b) recovery of unlawful aid (regardless of compatibility); (c) recovery of illegality interest; (d) damages for competitors and other third parties; and (e) interim measures against unlawful aid (EU Notice 2009, par. 26). Moreover, nullity of contracts on state aid was also rejected by some national courts, e.g. in Austrian Bank Burgenland, and Landesforstrevier L case (Gyárfaš, 2017, p. 458) or Slovak Trnava v City Aréna case.

\section{Public procurement}

Nullity or ineffectiveness of contracts concluded as an outcome of violated rules of public procurement was nor originally included in Remedies Directive of 1989 (EU Directive 1989) and the Member States used to rely on sacrosanctity of pacta sunt servanda principle, thus the contract can be declared null on the basis of national private law only. This argument was struck by the CJEU in Commission v Germany, rejecting objections of Germany, inter alia, "even if it were to be accepted that the principles of legal certainty and of the protection of legitimate expectations, the principle pacta sunt servanda and the right to property could be used against the contracting authority by the other party to the contract in the event of rescission, Member States cannot rely thereon to justify the non-implementation of a judgment establishing a failure to fulfil obligations under Article 226 EC and thereby evade their own liability under Community law". "The particular features of the system of property ownership in a Member State cannot therefore justify the continuation of a failure to fulfil obligations which consists of an obstacle to the freedom to provide services" and "a Member State cannot plead provisions, practices or situations prevailing in its domestic legal order to justify the failure to observe obligations arising under Community law..." (2007, par. 36-38).

The sanction of "ineffectiveness" of contracts concluded contrary to stipulated public procurement rules was introduced by the substantial revision of EU Directive 1989 by EU Directive 2007 (together also "Remedies Directive").

The Remedies Directive in Art. 2d thereof does call neither for absolute nullity of contracts, nor for unconditional ineffectiveness. First of all, the Remedies directive requires "ineffectiveness" of the contracts and private-law consequences, including termination of 
contracts refers to national legislation [Art. $2 \mathrm{~d}(2)$ thereof]. Comparing to this power of reviewing authority to declare ineffectiveness of the contract, the contracting authorities shall have power to terminate contract under Art. 73 EU Directive 2014 on specific occasions that, in fact, constitute the most serious violations of public procurement rules. ${ }^{1}$ On the other hand, the contracting authority has "right" to terminate the contract, while reviewing authority has "duty" to declare ineffectiveness of the contract.

The reviewing authorities shall have significant margin of appreciation, since they shall have power not to declare ineffectiveness of a contract concluded within the illegal public procurement, if "overriding reasons relating to a general interest require that the effects of the contract should be maintained." [Art. 2d(3) Remedies Directive].

Thus, there is no explicit rule of nullity of illegally awarded contracts as well as no express duty of contracting authorities to do so. Also the CJEU was reluctant to provide such a directive. In MedEval (2015, par. 40) the Court stressed the necessity of legal certainty and protection of successful tenderer from financial losses: "Rendering a contract concluded following a public procurement procedure ineffective puts an end to the existence and possibly the performance of that contract, which constitutes a significant intervention by the administrative or judicial authority in the contractual relations between individuals and State bodies. Such a decision can thus cause considerable upset and financial losses not only to the successful tenderer for the public contract in question, but also to the awarding authority and, consequently, to the public, the end beneficiary of the supply of work or services under the public contract in question. As is apparent from recitals 25 and 27 in the preamble to Directive 2007/66, the EU legislature placed greater importance on the requirement for legal certainty as regards actions for a declaration that a contract is ineffective than as regards actions for damages". In Rudigier, the CJEU did not find in EU law any general rule on ineffectiveness or nullity due to the violation of public procurement apart from ineffectiveness in specific cases defined in Art. 2d Remedies Directive: "On the other hand, EU legislation on the award of public contracts does not lay down a general rule that the unlawfulness of an act or omission at a given stage of the procedure renders unlawful all subsequent acts in that procedure and justifies their annulment. Only in specific well-defined situations does that legislation provide for such a consequence." (2017, par. 57).

However, on a basis of Commission v Germany, Halonen (2017) suggests that there is an obligation to terminate contract based on illegal public procurement since the Member States cannot maintain arrangement contrary to the EU law. This duty to terminate contract can be implicitly given by the duty of the Member States to safeguard functioning of internal market against obstacles to free movement of goods and services. Therefore, the duty to terminate contract based on EU law covers, at least, the most serious

\footnotetext{
${ }^{1}$ (a) The contract has been subject to a substantial modification, which would have required a new procurement procedure pursuant to Article 72;

(b) the contractor has, at the time of contract award, been in one of the situations referred to in Article 57(1) and should therefore have been excluded from the procurement procedure;

(c) the contract should not have been awarded to the contractor in view of a serious infringement of the obligations under the Treaties and this Directive that has been declared by the Court of Justice of the European Union in a procedure pursuant to Article 258 TFEU.
} 
infringement of public procurement rules that have significant impact on the freedoms of internal market, since EU public procurement regime is only expression of one of the tools aimed to remove obstacles to free movement of goods and services via harmonization pursuant to Art. 114 TFEU.

\section{Conclusions}

From the times of Roman law, question of nullity of contracts contravening public law appears to be simple - contract stemming from illegal acts shall be null and void. Contracts involved in agreements restricting competition, abuse of dominant position, mergers, state aid and public procurement have specific nature - their existence or nonexistence may influence functioning of market mechanism within the internal market of the EU. Bearing in mind this importance, one can assume that EU law is clear and straightforward regarding these contracts based on illicit or illegal behaviour. It appeared that we must draw a line between EU-law-based nullity and nullity based on national law. The scope of EU-law-based nullity is quite limited and only Art. 101(2) TFEU provides expressed nullity of agreements restricting competition. In the case of abuse of dominance nullity of contract constituting abuse of dominant position can be drawn from the principle of effectiveness of EU law. Validity or nullity of contracts violating suspension clause in merger control regime are assessed in two periods - before decision on merger (ineffectiveness due to principle of effectiveness of EU Law) and after decision of the Commission (follow legal destiny of the merger as a whole). Comparing to antitrust and merger control, state aid regime cannot rely on EU-law-based nullity of contracts that violate EU state aid rules. This question is completely left to the ambit of national law and there is no case law confirming at least implied duty to deem such contracts null and void.

Finally, public procurement rules appear the most complex in this context since they operate with the "right" of the contracting authority to terminate contract and power of revision authority to declare "ineffectiveness" of illegally awarded contract. The CJEU was definitely reluctant to provide exact guidance regarding nullity of illegally awarded contract, particularly out of the scope of "ineffectiveness", and left the assessment to the Member States. Although this self-restraint of the EU and its institutions can be welcomed from the point of view of proportionality, it does not contribute to clarity of the regime itself. It must be noted, that in the course of enlargement process when the European Commission critically reviewed progress of the countries of Western Balkan in the area of public procurement rules (2020a, 2020b, 2020c, 2020d, 2020e, 2020f $\mathrm{f}^{2}$ clear and precise rules on the side of the EU shall be prerequisite of existence and development of coherent and effective regulatory area. Therefore, it seems to be inevitable that requirement of nullity of illegally awarded contracts shall be established within the revision of public procurement directive for the cases of the most serious infringement of public procurement rules.

\footnotetext{
${ }^{2}$ Regarding the using name of Kosovo the European Commission in the report stated, that this designation „is without prejudice to positions on status, and is in line with UNSCR 1244(1999) and the ICJ Opinion on the Kosovo declaration of independence." (2020f, p. 1).
} 


\section{References}

Besselink, L. F. M. 2010. National and constitutional identity before and after Lisbon. Utrecht Law Review, 6(3), pp. 36-49. https://doi.org/10.18352/ulr.139.

Cortese, B. 2020. State Aid Law as a passepartout: Shouldn't We Stop Taking the Effect on Trade for Granted?. Bratislava Law Review, 4(1), pp. 9-18. https://doi.org/10.46282/ blr.2020.4.1.194.

Delicostopoulos, J. S. 2003. Towards European Procedural Primacy in National Legal Systems. European Law Journal, 9(5), pp. 599-613. https://doi.org/10.1046/j.14680386.2003.00194.x.

Goyder, J. \& Dons, M. 2017. Damages Claims Based on State Aid Law Infringements. European State Aid Law Quarterly, 16(3), pp. 416-428. https://doi.org/10.21552/ estal $/ 2017 / 3 / 10$

Gyárfaš, J. 2017. Hic Sunt Leones: Private Enforcement of State Aid Law in Slovakia. European State Aid Law Quarterly, 16(3), pp. 453-467. https://doi.org/10.21552/ estal/2017/3/14.

Halonen, K.-M. 2017. Termination of a Public Contract - lifting the veil on Art. 73 of 2014/24 Directive. Public Procurement Law Review, 5, pp. 187-198.

Honoré, M., \& Jensen, N. E. 2017. Damages in State Aid Cases. European State Aid Law Quarterly, 10(2), pp. 265-286. https://doi.org/10.21552/estal/2011/2/227.

Jouve, D. 2017. Recovering Unlawful and Incompatible Aids by National Courts: CELF and Scott/Kimberly Clark Cases. European State Aid Law Quarterly, 16(3), pp. 366-376. https://doi.org/10.21552/estal/2017/3/6.

Köhler, M. 2017. Private Enforcement of State Aid Law - Problems of Guaranteeing EU Rights by means of National (Procedural) Law. European State Aid Law Quarterly, 11(2), pp. 369-387. https://doi.org/10.21552/estal/2012/2/279.

Kubera, P. 2020. State Aid rules and public financing of infrastructure. The Case of Autostrada. TalTech Journal of European Studies, 10(1), pp. 77-96. https://doi. org/10.1515/bjes-2020-0005.

Martin-Ehlers, A. 2017. Private Enforcement of State Aid Law in Germany. European State Aid Law Quarterly, 10(4), pp. 737-740. https://doi.org/10.21552/estal/2011/4/255.

Mock, S. 2002. Harmonization, Regulation and Legislative Competition in European Corporate Law. German Law Journal, 3(12), E5. https://doi.org/10.1017/ S2071832200015649.

Nazzini, R. 2006. Article 81 EC between time present and time: A 'normative critique' of restriction of competition in EU law. Common Market Law Review, 43(2), pp. 497-536.

O'Donoghue, R. \& Padilla, J. 2020. Law and Economics of Article 102 TFEU. Bloomsbury Publishing.

Ordóñez-Solís, D. 2017. Waiting for National Judges in Infringement Proceedings on State Aid. European State Aid Law Quarterly, 16(3), pp. 377-392. https://doi. org/10.21552/estal/2017/3/7. 
Pärn-Lee, E. 2020. The Origins of Supranational State Aid Legislations : What Policymakers Must Know and Adhere to. The Case of Estonia. TalTech Journal of European Studies, 10(1), pp. 123-145. https://doi.org/10.1515/bjes-2020-0007.

Pastor-Merchante, F. 2016. The Protection of Competitors under State Aid Law. European State Aid Law Quarterly, 15(4), pp. 527-538. https://doi.org/10.21552/estal/2016/4/5.

Pinto, C. S. 2016. The "Narrow" Meaning of the Legitimate Expectations Principle in State Aid Law Versus the Foreign Investor's Legitimate Expectations. European State Aid Law Quarterly, 15(2), pp. 270-285.

Ritzenhoff, L. 2014. Legitimate Expectations in Reasonable Delay - Regional aid to Hotels in Sardegna. European State Aid Law Quarterly, 13(4), pp. 729-734.

Scalise, R. J. 2014. Rethinking the Doctrine of Nullity. Louisiana Law Review, 74(3), pp. 663-718.

Schmid, D. 2002. (Do) We Need a European Civil Code (?). Annual Survey of International \& Comparative Law, XVIII(1), pp. 263-293.

Stehlík, V. 2018. Interim measures before national courts in the context of EU and Czech law. International and Comparative Law Review, 12(2), pp. 7-42. https://doi. org/10.1515/iclr-2016-0084.

Weatherill, S. 2012. Maximum versus Minimum Harmonization: Choosing between Unity and Diversity in the Search for the Soul of the Internal Market. In: Shuibhne, N.N. \& Gormley, L. (eds.), From Single Market to Economic Union. Oxford: Oxford University Press, pp. 175-199. https://doi.org/10.1093/acprof:oso/9780199695706.003.0010. Zingales, N. 2010. Member State Liability vs. National Procedural Autonomy: What Rules for Judicial Breach of EU Law?. German Law Journal, 11(4), pp. 419-438. https:// doi.org/10.1017/S2071832200018617.

\section{Website references}

OECD. 2019. Suspensory Effects of Merger Notifications and Gun Jumping. Available at: https://one.oecd.org/document/DAF/COMP(2018)11/en/pdf.

\section{Legal sources}

European Commission (2020a). Albania 2020 Report. Commission Staff Working Document. Brussels, 6.10.2020, SWD (2020) 354 final. Available at: https://ec.europa.eu/ neighbourhood-enlargement/sites/near/files/albania_report_2020.pdf

European Commission (2020b) Montenegro 2020 Report. Commission Staff Working Document. Brussels, 6.10.2020, SWD (2020) 353 final. Available at: https://ec.europa. eu/neighbourhood-enlargement/sites/near/files/montenegro_report_2020.pdf

European Commission (2020c). North Macedonia 2020 Report. Commission Staff Working Document. Brussels, 6.10.2020, SWD (2020) 351 final. Available at: https://ec.europa. eu/neighbourhood-enlargement/sites/near/files/north_macedonia_report_2020.pdf European Commission (2020d). Serbia 2020 Report. Commission Staff Working Document. Brussels, 6.10.2020, SWD (2020) 352 final. Available at: https://ec.europa.eu/ neighbourhood-enlargement/sites/near/files/serbia_report_2020.pdf 
European Commission (2020e). Bosna and Herzegovina 2020 Report. Commission Staff Working Document. Brussels, 6.10.2020, SWD (2020) 350 final. Available at: https://ec.europa.eu/neighbourhood-enlargement/sites/near/files/bosnia_and_ herzegovina_report_2020.pdf

European Commission (2020f). Kosovo 2020 Report. Commission Staff Working Document. Brussels, 6.10.2020, SWD (2020) 350 final. Available at: https://ec.europa.eu/ neighbourhood-enlargement/sites/near/files/kosovo_report_2020.pdf

EU Directive 1989. Council Directive 89/665/EEC of 21 December 1989 on the coordination of the laws, regulations and administrative provisions relating to the application of review procedures to the award of public supply and public works contracts. OJ L 395, 30.12.1989, p. 33-35.

EU Directive 2007. Directive 2007/66/EC of the European Parliament and of the Council of 11 December 2007 amending Council Directives 89/665/EEC and 92/13/EEC with regard to improving the effectiveness of review procedures concerning the award of public contracts (Text with EEA relevance ). OJ L 335, 20.12.2007, p. 31-46.

EU Directive 2014. Directive 2014/24/EU of the European Parliament and of the Council of 26 February 2014 on public procurement and repealing Directive 2004/18/EC Text with EEA relevance. OJ L 94, 28.3.2014, p. 65-242.

EU General Block Exemption Regulation 2010. Commission Regulation (EU) No 330/2010 of 20 April 2010 on the application of Article 101(3) of the Treaty on the Functioning of the European Union to categories of vertical agreements and concerted practices (Text with EEA relevance) OJ L 102, 23.4.2010, p. 1-7

EU Notice 2009. Commission notice on the enforcement of State aid law by national courts. OJ C 85, 9.4.2009, p. 1-22.

EU Regulation 2003. Council Regulation (EC) No 1/2003 of 16 December 2002 on the implementation of the rules on competition laid down in Articles 81 and 82 of the Treaty (Text with EEA relevance) OJ L 1, 4.1.2003, p. 1-25

EU Regulation 2004. Council Regulation (EC) No 139/2004 of 20 January 2004 on the control of concentrations between undertakings (the EC Merger Regulation) (Text with EEA relevance) OJ L 24, 29.1.2004, p. 1-22

EU Regulation 2015. Council Regulation (EU) 2015/1589 of 13 July 2015 laying down detailed rules for the application of Article 108 of the Treaty on the Functioning of the European Union. OJ L 248, 24.9.2015, p. 9-29.

Ahmed Saeed Flugreisen and Silver Line Reisebüro GmbH v Zentrale zur Bekämpfung unlauteren Wettbewerbs e.V. Judgment of the Court of 11 April 1989. Case 66/86. ECLI:EU:C:1989:140

Béguelin Import Co. v S.A.G.L. Import Export. Judgment of the Court of 25 November 1971. ECLI:EU:C:1971:113

Belgische Radio en Televisie a société belge des auteurs, compositeurs et éditeurs v SV SABAM a NV Fonior (BRT II). Judgment of the Court of 37 March 1974. Case 127-73. ECLI:EU:C:1974:25 
CELF I. Centre d'exportation du livre français (CELF) and Ministre de la Culture et de la Communication $v$ Société internationale de diffusion et d'édition (SIDE). Judgment of the Court (Grand Chamber) of 12 February 2008. Case C-199/06. EU:C:2008:79

CEPSA Estaciones de Servicio SA $v$ LV Tobar e Hijos SL. Judgment of the Court (Third Chamber) of 11 September 2008. Case C-279/06. ECLI:EU:C:2008:485

Commission v Germany. Judgment of the Court (Second Chamber) of 18 July 2007. Case C-503/04. ECLI:EU:C:2007:432

Éditions Odile Jacobv Commission. Judgment of the Court (Grand Chamber), 6 November 2012, Case C-551/10 P, ECLI:EU:C:2012:681

Ernst \& Young P/S v Konkurrencerådet. Judgment of the Court (Fifth Chamber) of 31 May 2018. Case C-633/16. ECLI:EU:C:2018:371

Etablissements Consten S.à.R.L. and Grundig-Verkaufs-GmbH v Commission of the European Economic Community. Judgment of the Court of 13 July 1966. Joined cases 56 and 58-64. ECLI:EU:C:1966:41

MedEval - Qualitäts-, Leistungs- und Struktur-Evaluierung im Gesundheitswesen GmbH. Judgment of the Court (Fifth Chamber) of 26 November 2015. Case C-166/14. ECLI:EU:C:2015:779

SA Brasserie de Haecht $v$ Wilkin-Janssen. Haecht II. Judgment of the Court of 6 February 1973. Case 48-72. ECLI:EU:C:1973:11

Société de Vente de Ciments et Bétons de l'Est SA v Kerpen \& Kerpen GmbH und Co. KG. Judgment of the Court (Fourth Chamber) of 14 December 1983. Case 319/82. ECLI:EU:C:1983:374

Société Technique Minière (L.T.M.) v Maschinenbau Ulm GmbH (M.B.U). Judgment of the Court of 30 June 1966. Case 56-65. ECLI:EU:C:1966:38

Stefan Rudigier. Judgment of the Court (Ninth Chamber) of 20 September 2018. Case C-518/17. EU:C:2018:757

VAG France SA v Établissements Magne SA. Judgment of the Court (Third Chamber) of 18 December 1986. Case 10/86. ECLI:EU:C:1986:502

Slovakia, Judgment of 14 September 2018, Mesto Trnava v City-Arena, a.s., City-Arena PLUS, a.s., case No 39C/30/2017, ECLI:SK:2117221806. 


\title{
Dr Ondrej Blažo
}

Vanredni profesor, Pravni fakultet, Comenius univerzitet, Bratislava, Slovačka e-mail: ondrej.blazo@flaw.uniba.sk

\section{NIŠTAVOST I NEPUNOVAŽNOST UGOVORA KAO POSLEDICA KRŠENJA PRAVA KONKURENCIJE EU I PRAVILA O JAVNIM NABAVKAMA}

\author{
Sažetak
}

Rad će se fokusirati na zahteve koje postavlja pravo EU u pogledu ništavosti i nepunovažnosti ugovora $u$ određenim oblastima koje su povezane sa funkcionisanjem unutrašnjeg tržišta: pravo konkurencije, uključujući restriktivne sporazume, zloupotrebu dominantnog položaja, kontrolu koncentracija i državnu pomoć i pravila o javnim nabavkama. Domen primene pravila o ništavosti koja su zasnovana na pravu EU je ograničen i samo je u čl. 101 (2) Ugovora o funkcionisanju Evropske unije izričito predviđena ništavost restriktivnih sporazuma. U slučaju zloupotrebe dominantnog položaja, ništavost ugovora može da proistekne iz principa efikasnosti prava EU. Punovažnost ili ništavost ugovora koji krše klauzulu suspenzije u režimu kontrole koncentracija se procenjuje u dva trenutka - pre odluke o spajanju i nakon odluke Evropske komisije. Režim državne pomoći ne može da se oslanja na ništavost ugovora kojima se krše pravila EU o državnoj pomoći na osnovu prava EU. Konačno, pravila o javnim nabavkama su, čini se, najsloženija u tom smislu, jer funkcionišu u smislu „prava“ ugovorne strane da raskine ugovor i ovlašćenja tela koje vrši reviziju da proglasi „nepunovažnim“ ugovor koji je nelegalno dodeljen. Stoga se predlaže revizija direktiva.

Ključne reči: pravo Evropske unije, pravo konkurencije, javne nabavke, ništavost, nepunovažnost.

Article history:

Received: 30 November 2020

Revised: 1 January 2021

Accepted: 20 January 2021 